\title{
One Dream One World-A Comparison of the Protagonists' Destines in Great Expectations and The Great Gatsby
}

\author{
Jing Jing \\ Jing Xia \\ Changchun University, Changchun, China \\ No. 20 Junior Middle School of Siping, Siping, China

\begin{abstract}
In this paper, the author chooses Great Expectations and The Great Gatsby, the two great works in English and American literature respectively, to analyze the similarities and differences of the two protagonists' "great dreams" and their different destinies. By analyzing and comparing the protagonists' characteristics and their destinies in the two different works produced under similar social and historical backgrounds, we can see that one's real worth and value lies in the conscience and affection rather than wealth and social status.
\end{abstract}

Keywords: American Dream, Gatsby, Great Expectations, The Great Gatsby

\section{Introduction}

Great Expectations is a novel by Charles Dickens. It depicts the growth and personal development of an orphan named Pip. There are three major themes in Great Expectations, namely: (a) ambition and self-improvement; (b) social class; and (c) crime, guilt, and innocence. Dickens establishes the moral theme that affection, loyalty, and conscience are more important than social advancement, wealth, and class and shows Pip to learn this lesson, largely by exploring the ideas of ambition and self-improvement-ideas that quickly become both the thematic center of the novel and the psychological mechanism that encourages much of Pip's development (Chen, 2003).

The Great Gatsby is a novel by the American author F. Scott Fitzgerald. The book was first published in 1925, and it was republished in 1945 and 1953. The Modern Library named it the second best English-language novel of the 20th century. In The Great Gatsby, Fitzgerald shows how the American Dream is full of materialism, and how materialism influences the lives of people and makes it hard for people to see the reality objectively.

Great Expectations reveals the hypocrisy of the Victorian civilization in England from the perspective of capitalist humanism and discloses the serious problems and nature of the society (Wilson, 1970). While in The Great Gatsby, the author tells from the view of Nick and talks about the disillusionment of Gatsby's American Dream. Although the two stories are told in different countries, their similar social circumstances and historical backgrounds make them have a lot that can be compared. In this thesis, the authors attempt to analyze and compare the similarities and differences of the protagonists' dreams and destinies from the perspective of "great dream" and to appeal the regression of human morality and spiritual civilization.

Jing Jing, M.A., lecturer, School of Foreign Languages, Changchun University.

Jing Xia, B.A., lecturer, No. 20 Junior Middle School of Siping. 


\section{Similarities of Their Destinies}

The protagonists in Great Expectations and The Great Gatsby both share similarities of their destinies. First, the protagonists set the heroines as their "great dreams," but their way to pursue their love does not seem to run smoothly. In order to win the love of the heroines, they make great efforts to equip themselves with abundant wealth and social status. Second, on the way to pursue their dreams, they both meet people who help them a lot reach to where they want to go and to gain what they want.

The main heroine in Great Expectations is Estella. On the protagonists' way to pursue their "great dreams," they both meet their own goddesses. The heroines in both of the works share similar characteristics, and they exert influences on the protagonists' life and destinies on a large scale. When it comes to the heroine Estella in Great Expectations, often cited as Dickens's first convincing female character, Estella is a supremely ironic creation, one who darkly undermines the notion of romantic love and serves as a bitter criticism against the class system in which she mires. Raised from the age of 3 by Miss Havisham to torment men and "break their hearts," Estella wins Pip's deepest love by practicing deliberate cruelty. Unlike the warm, winsome, and kind heroine of a traditional love story, Estella is cold, cynical, and manipulative. Though she represents Pip's first longed-for ideal of life among the upper classes, Estella is actually even lower-born than Pip. Near the end of the novel, Pip learns that she is the daughter of Magwitch, the coarse convict, and thus springs from the very lowest level of society. Ironically, life among the upper classes does not represent salvation for Estella. Instead, she is victimized twice by her adopted class. Rather than being raised by Magwitch, a man of great inner nobility, she is raised by Miss Havisham, who destroys her ability of emotion and interact normally with the world. And rather than marrying the kindhearted commoner Pip, Estella marries the cruel nobleman, who treats her harshly and makes her life miserable for many years. In this way, Dickens uses Estella's life to reinforce the idea that one's happiness and well-being are not deeply connected to one's social position. Had Estella been poor, she might have been substantially better off (Rosenberg, 1999). Despite her cold behaviors and the damaging influences in her life, Dickens nevertheless ensures that Estella is still a sympathetic character. By giving the reader a sense of her inner struggle to discover and act on her own feelings rather than on the imposed motives of her upbringing, Dickens gives the reader a glimpse of Estella's inner life, which helps to explain what Pip might love her. At the end of the story, Estella does not seem able to stop herself from hurting Pip, but she also seems not to want to hurt him, she repeatedly warns him that she has "no heart" and seems to urge him as strongly as she can to find happiness by leaving her husband. Finally, Estella's long, painful marriage causes her to develop along the same lines as Pip, that is, she learns, through experience, to rely on and trust her inner feelings. In the final scene of the novel, she has become herself for the first time in the book. As she says to Pip, "Suffering has been stronger than all other teaching ... I have been bent and broken, but-I hope-into a better shape" (Dickens, 2010).

In terms of the heroine in The Great Gatsby, Daisy is Gatsby's "golden girl." She is a beautiful young woman who always wears in white dresses, a symbol of her levity and lack of character. She is Nick's cousin and the object of Gatsby's love but actually never worthy of this adoration. As a young debutante in Louisville, Daisy is courted by a number of officers, including Gatsby. Gatsby lies about his background to Daisy and, eventually, he wins Daisy's heart. Daisy promises to wait for Gatsby. However, she seems to have no inner self which could make solitude bearable and she harbors a deep need to be loved, and when a wealthy, powerful young man named Tom Buchanan who could promise her a wealthy lifestyle and who has the support of her 
parents proposes to her, Daisy decides not to wait for Gatsby after all. Since then, Gatsby dedicates himself to winning Daisy back, making her the single goal of all of his dreams and the symbol of everything he desires behind seeking after immense wealth by illegal transactions. To Gatsby, Daisy represents the paragon of perfection - she has the aura of charm, wealth, sophistication, grace, and aristocracy that he longs for since childhood. In reality, however, Daisy falls far short of Gatsby's idealism. Indeed, she stands for the material wealth to Gatsby. This association points to the weakness of Gatsby's dream and indicates its inevitable destruction. Daisy is charming, but also fickle, shallow, and somewhat cynical, and behaves superficially to mask her pain at her husband's constant infidelity. When Nick does the favor to rekindle the romance between her and Gatsby, she again has an affair with Gatsby but it is just a relief from her boredom. Daisy proves her real nature when she chooses Tom over Gatsby, for she enjoys the wealth and social prominence that her marriage brings, which obviously marks her parasitic side. She allows Gatsby to take the blame for killing Myrtle Wilson and moves away with her husband and never takes any responsibility. Daisy is fond of money, ease, and material luxury. She is capable of affection, but not of sustained loyalty or care.

When talking about the protagonists' destinies, it is inevitable to mention the heroines in the two works. It is them who change the life of Pip and Gatsby. In both of the works, the heroines, Estella and Daisy, actually, are the real embodiment of the protagonists' "great dreams." Pip and Gatsby set Estella and Daisy respectively as their ideal dreams. Yet, it is just this kind of false interpretation of their ideal dreams that finally make them suffer a lot. So, the role of the heroines should be highlighted rather than neglected.

On their way to realize their great dreams, Pip and Gatsby both meet their helpers, who play an indispensable role in their life. In Great Expectations, Pip meets Magwitch, who is a criminal and is saved by Pip. In order to pay back Pip, Magwitch gives financial assistance to Pip to help him grow into a real gentleman in London. Initially after the revelation, Pip's reaction had been one of shock, disbelief, and even repugnance. However, he still tries what he can to repay him for his financial support. At the very beginning, Pip does not know it is Magwitch that patronizes him, while when he discovers the truth, his great expectation and dream crash at the same time, for Magwitch is not only the criminal who Pip ever saved, but also is the real father of Estella who is Pip's true love. On the one hand, his mood and expectations towards future go down to the very lowest point, because after all those years of what he had experienced and struggled for pursuing Estella's love as well as his own great expectations, he suddenly finds out the truth which frustrates him completely. On the other hand, Magwitch's behavior of supporting Pip through all those years anonymously touches Pip a lot, and appeals to Pip's inner regression to morality. When Magwitch is in trouble, he helps him flee the country. Although he is unsuccessful in fleeing the country with Magwitch, his caring and devotion for Magwitch are unwavering despite the fact that he will not receive any money after Magwitch's death. So we can see that Magwitch does not only help Pip in financial aspect, but much in arousing Pip's innate nature, which brings his moral state of mind into a higher position, and this helps Pip regain his great expectations as well as his positive nature.

Compared with Magwitch in Great Expectations, in The Great Gatsby, by accidental, Gatsby meets Dan Cody, who changes Gatsby's whole life. Dan Cody's process of getting rich lets Gatsby see hope, so Gatsby works very hard together with Dan Cody, hoping that one day he would become a person like him. While, Gatsby does not see that although with hundreds of thousands of legacy, Dan Cody still could not possess a position which is deeply influenced by European hierarchy in the American society. Although finally the life ending of Gatsby is a tragedy, Dan Cody still plays a very important role in Gatsby's way to pursue his "great dream." 
To sum up, Magwitch and Dan Cody, the two helpers of Pip and Gatsby respectively, help Pip and Gatsby reach to where they want to go and gain what they want to some degree. They both play a very important role in influencing the destinies of the protagonists ( $\mathrm{Hu}, 2010)$.

\section{Differences of Their Destines}

Although the two protagonists share a lot in common in their destinies, their life endings are totally different. Pip in Great Expectations wins back the love of Estella, and they start to have their own great expectations finally, while Gatsby in The Great Gatsby fails to regain his love and is falsely incriminated by Daisy.

In Great Expectations, in order to win Estella's love, Pip vowed to change himself, become uncommon, and become a real gentleman. Although Estella has been sent abroad to receive the education of being an elegant upper class lady, his love to Estella grew stronger and stronger and he even had the fantasy that someday Miss Havisham will bestow the beautiful Estella on him. He regarded Estella as the elegant princess. As years went by, Pip was still living the same wasteful life of a wealthy young man in the city. Not until Estella married another man did he realize that all his expectations were based on the dirty money, and he realized that Estella was not the elegant girl as he has imagined as before. He realized that in order to make his dream come true, he has abandoned his original honesty and kindness. His mood fell down suddenly from the great high to depression, and this is just the climax of the whole story. Fortunately, at last, Miss Havisham had woken up from the false standard of measuring morality, and Estella also realized who she truly loved. The ending of the story was that Pip and Estella were reunited in the garden, and it can be concluded to be a happy ending for Pip, when Pip finally found out all the truths, his conscience came back to life. He helped Magwitch to get away from arrest and he realized all the years' devotion of his sister-in-law Joe. Moreover, he could clearly recognize himself although he had already become poor again. When he saw Estella in the garden several years later, they reunited together and Pip won his love of Estella. So the end of the story marks the real great expectations of Pip and Estella (Dickens, 2010).

Compared with the ending of Pip in Great Expectations, Gatsby' life ending seems to be more sympathetic. At the end of the story, Gatsby is set up by Daisy and her husband Tom. Gatsby wants Daisy to leave her husband Tom, but when Daisy knows the truth of Gatsby, she becomes afraid of losing the steady social status and the luxuriant lifestyle. So, with a bad mood, she drives the car and accidentally kills Tom's mistress, Ms. Wilson. In order to protect Daisy, Gatsby shoulders the responsibility of killing Ms. Wilson. Tom, with great jealousy, imputes his adultery and Daisy's criminal of killing to Gatsby and tempts Mr. Wilson to kill Gatsby, and after that, Mr. Wilson commits suicide. At the funeral of Gatsby, only Nick is present, Daisy does not come but goes to Europe with Tom together.

Fitzgerald shows how Gatsby almost fulfills the dream having all of its requirements: position, money, and his unique perception of the world that "attracted" people. Besides, "ideal love" was nevertheless not fulfilled and it started the collapse of the "American Dream." For love cannot be bought with anything. He makes all the money with the only aim, which he knows that Daisy wants to marry a rich man, therefore he considers this way to be the only way to unite him with his true love. The understanding of the dream by the characters in the book is garbled and that is the primary reason they fail to realize the true message of the dream.

Fitzgerald reveals to the readers that happiness is not a thing, which you can buy with money or handpick with power. Fitzgerald's "American Dream" is a dream with the same name, but with a different content. 
Having money is not a guarantee of true happiness (Mizener, 1951). At the end of the story, Gatsby is ready to put her guilt over his shoulders, and the last scene shows how much love and devotion valued and how responsible can these "American Dream seekers" be. So, after seeing the whole lifetime of Gatsby, we can see his greatness of pursuing his "American Dream" compared with other people at his time, due to which Gatsby can really be called the great.

\section{Conclusion}

The protagonists Pip in Great Expectations and Gatsby in The Great Gatsby share commonalities. They both have humble origins when they fell in love with the young ladies. Virtually, they hope that they can have a bright future and great expectations to realize their dream of becoming a better man, while they twist their dreams and seem to be too eager to be successful. They regard winning their love of the heroines as their "great dreams." So in order to live up to their unrealistic dreams to become a wealthy man with a high social status, they throw away their positive nature, which in turn makes them suffer a lot in the end. Although with a lot in common in pursuing their "great dreams," their life endings differ greatly. Pip reunites with Estella in the garden, and they both realize that to pursue unrealistic dreams is wasteful and insignificant. But it seems that Gatsby is too blindly persistent in winning the love of Daisy, which is actually the embodiment of his "American Dream," and finally is falsely incriminated by Daisy and Tom.

To conclude, the word "Great" in both the titles can be endowed with two layers of meanings. On one hand, it sarcastically criticizes the unrealistic dreams of pursuing material values that the protagonists hold. On the other hand, at a time when extravagance and materialism comes first, the protagonists still harbor hopes and dreams, and can persist in them. By analyzing and comparing the protagonists' characteristics and their destinies in the two different works, we can see that one's real worth and value lies in the conscience and affection rather than wealth and social status. Again, this paper tries to emphasize the significance of rebuilding people's spiritual civilization and the regression of human morality.

\section{References}

Chen, J. (2003). A history of English literature. Beijing: The Commercial Press.

Dickens, C. (2010). Great expectations. Xi'an: Global Book Press.

Hu, Y. T. (2010). American literature. Beijing: Foreign Language Teaching and Research Press.

Mizener, A. (1951). The far side of paradise: A biography of F. Scott Fitzgerald. Boston, M.A.: Houghton Mifflin.

Rosenberg, E. (Ed.). (1999). Great expectations. New York, N.Y.: Norton.

Wilson, A. (1970). The world of Charles Dickens. London, U.K.: The Book Society.

Zhang, D. Q., \& Wu, G. (2002). A new concise history of English literature. Shanghai: Foreign Language Education Press. 